\title{
TEACHER'S ATTITUDE TOWARD DISCIPLINARY ACTIONS FOR SCHOOL CHILDREN: GENDER PERSPECTIVE
}

\author{
Samidha Dhungel Pokharel
}

\begin{abstract}
Gender discrimination is an emerging issue of an individual right after his/her birth. Intentional gender discrimination/ gender differentiated behavior can be seen and feel both in private and public life. This study aims to documents the teacher's gender differentiated behavior while disciplining the school children and to analyze the factors associated with such behavior. The study was designed as a descriptive study based on sample survey. The totals of 119 teachers from 60 schools were randomly chosen as respondents at the time of school visit. The study reveals the different types of disciplinary actions used by male and female teachers for different reasons. Male teachers are more concerned with the sex of students than female teachers while applying disciplinary techniques. School boys are the victim of gender differentiated behavior of the teachers because of gender discriminatory perceptions.
\end{abstract}

Key words: Discrimination, Disciplinary techniques, Differentiated behavior, Sex, Nepal, School teacher.

\section{INTRODUCTION}

It has been well recognized that gender discrimination, the product of gender socialization, starts from the very beginning of the life and continue through out the life (HMG; Culture, Tourism and Ministry of Civil Aviation, UNDP, TRPAP, 2006; UNICEF, 2007) Gender socialization starts in the form of differentiation between boys and girls during early child hood and later on it turns into discrimination (Thorne, 1993). Family/home, Medias, school/educational institution all play an important role in the socialization of gender (Pokharel, 2002) In school, students are influenced by two sets of socialization agents: the classroom teacher (and related school personnel) and peers (Tasmajian, 2002). Teacher's and peer's influence can have long lasting impact on children's life.

\section{DISCIPLINARY ACTIONS/TECHNIQUES}

Children learn many valuable skills like interaction with people; compete and cooperate in the way that society permits, and respect authority. In order to make the children acumen, many schools have developed the policy of disciplinary actions and are being practiced. Students are demanded to be inactive, and follow the school/class room's rule in the name of discipline unquestioned (Ganter and Yeakel, 1980). Nepal the traditional society, still follows the traditional method of education where almost 40 percent of corporal punishment cases take place in schools (Kathmandu Post 2005, June 27). Violation of the rule causes different types of punishment in the name of school

Mrs. Dhungel Pokhrel is Lecturer at Padma Kanya Multiple Campus T.U., Bagbajar, Kathmandu, Nepal. 
discipline. Students get the punishment for various reasons such as imperfect dress, untidiness, and incomplete home assignment, low performance et cetera (Pokharel et al., 2010). Researches have revealed that the training received by the teachers reduce the action taken to the students and enhance the teacher's skill to modify student's unwanted behavior in a positive way (Pokharel et al., 2010). Acknowledging the fact, the ministry of education, Nepal government had offered different types of teachers training in different parts of Nepal (Kantipur 2005). But the problem has remained the same, though the teachers are more aware about the negative impact of punishment. Some teachers have expressed their satisfaction and skill development with training. Despite of teachers training, many cases of punishment can still be read in the newspapers (Rajdhani, 2008; Naya Patrika, 2009; Kantipur, 2010). As punishments become an issue in school, teachers and administration apologize/ commit for not repeating the mistakes or even displace the teacher (Rajdhani, 2009). The displacement of the teacher from particular school is not the ever lasting solution because after displacement the teacher might join another school, and repeat the same mistake due to lack of knowledge Pokharel et al. (2010).

\section{GENDER DIFFERENTIATED BEHAVIOR AND SCHOOL CHILDREN}

As the children go to school discrimination/differentiation is reinforced in educational institutions. While teaching them reading, writing, and arithmetic, however, the schools also imbue them with sexist values. They do so through the pattern of staffing (male principals and custodian, female teachers and food servers), the curriculum materials, the sex segregation of sports and activities, and differential expectations of boys and girls. Sex segregation starts from the pre school age and continue throughout the elementary, middle and high schools. Sex segregation is well established by middle child hood (Eder and Hallinan, 1978; Schofield, 1981). It has been reported that teachers interact and respond male students than the female. Though the teachers respond the female students their response might be either neutral or negative (Houston, 1987). Boys and girls sit in the same class room, learn same lesson and expected to follow same rules, teachers respond in different way. Teachers encourage girls to be neat, quiet, and calm whereas boys to think independently, active, and speak up (Bailey, 1992). More over, in an educational setting there could be discrimination between boys and girls by excluding /including or encouraging/discouraging certain groups from educational institution, choosing specific subjects, or participation in certain activities. One day my daughter students of BBA who was assigned as captain of the sports came to the home and said "I am so disappointed that one of my male teachers requested all of the male students in the meeting and said no need to come for girls". She claims that a student was excluded from an educational institution, program, and opportunity, student group, due to her gender (Author, 2010).

\section{OBJECTIVES OF THE STUDY}

The general objective of the study is to document the disciplinary actions taken by the male and female teachers to the male and female students in schools. The specific objectives are:

(1) To understand whether the teachers (male and female) apply different type of disciplinary actions/ techniques. 
(2) To analyze the factors associated with reason for taking actions and considering the sex of the students by male and female teachers while selecting disciplinary actions, if any.

\section{RESEARCH METHODOLOGY}

The study is descriptive in nature. However it explores the method of disciplinary techniques used by the male and female teachers. Data were collected through a set of open and close ended questionnaire during school session (2067 Baishakh to 2067 Bhadra) with the permission of school administration. The research study is based on primary data collected from the total of 119 teachers 60 schools located at Kathmandu valley (Kathmanu. Lalitpur and Bhaktapur districts). The schools which offer education up to class eight including community and organization type were selected from the list provided by the Ministry of Education (MOE). The male and female teachers were immediately selected randomly at the time of school visit. An attention was paid to cover all of the classes. Data has been analyzed with Statistical Package for Social Science (SPSS/PC+) computer software. A chi square test also has been run to test the significance difference between male and female teacher.

\section{RESULTS}

\section{TEACHERS (GENDER WISE) AND DISCIPLINARY ACTIONS/TECHNIQUES}

Table (1) shows that majority of the male and female teachers use multiplicity of techniques/action to make school children disciplined at different levels. Along with verbal warning/counseling, other common disciplinary actions applied by the teachers are making students ashamed, stand in front of the class mates or in front of seniors and juniors; sending the students to the office if $\mathrm{S} / \mathrm{he}$ is not controlled by regular teacher, spanking, talk/complain to the parents, sit ups, and threatening. Insignificant number of teachers were also found to be using other types of disciplinary actions which were not mentioned in the questionnaire were: ask another student to bang on the back trunk of those committing mistakes, asking the question from the lesson, some time to make students harassed, they (students) are brought in front of other students and demanded to answer the questions from the lesson, comparing with the good students, giving extra home works, keeping students in junior class, staring, threaten with a stick, keeping students after class and making them finish their home works etcetera. As well as threatening and sending students to the office, other types of techniques are used by the male teachers. While spanking, shaming and making students stand up are more commonly used by the female teachers. 
Table 1: Types of Disciplinary Actions Used by the Teachers

\begin{tabular}{|l|c|c|}
\hline \multicolumn{1}{|c|}{ Disciplinary actions } & \multicolumn{2}{c|}{$\begin{array}{c}\text { Response in percentage } \\
\text { by gender }\end{array}$} \\
\cline { 2 - 3 } & Male & Female \\
\hline Verbal & 98.2 & 95.3 \\
\hline Shaming & 23.6 & 28.1 \\
\hline Standing in front & 38.2 & 40.6 \\
\hline Sending students to Discipline In-charge at school & 38.2 & 23.4 \\
\hline Spanking & 27.3 & 39.1 \\
\hline Talking to Parents & 56.4 & 56.3 \\
\hline Sit ups & 23.6 & 26.6 \\
\hline Threatening & 43.6 & 28.1 \\
\hline Other & 18.2 & 9.4 \\
\hline
\end{tabular}

\section{REASON FOR TAKING ACTIONS}

Different behaviors like not doing home work, talking in the class room, inappropriate uniforms or not wearing uniforms, fight with friends and disobeying the teachers were common reason associated with taking actions. Study show that more than three fourth of the respondents (male $94.4 \%$, female $79.7 \%$ ) are concerned with school children's attitude of not doing home work and take actions. This study also aims to understand if the male and female teachers are concerned with student's same type of behavior of the students or not (Table 2). Male teachers were found to be more concerned with student's attitude of not doing home work, violation of school rule, use of non formal (slum) language. Student's other behavior outside the school compound like association with outsider addicted children, gang fight, illegal activities like stealing, was also a great concern of the male teachers. Female teachers were relatively more succinct within the class room and the reason for taking actions were switching food and stationary, fighting in the classroom, not attentive in the class room, girls teasing attitude of boys, and stealing friend's goods.

Table 2: Reason for Taking Actions

\begin{tabular}{|l|c|c|}
\hline \multicolumn{1}{|c|}{ Reasons } & \multicolumn{2}{c|}{$\begin{array}{c}\text { Response in percentage } \\
\text { by gender }\end{array}$} \\
\cline { 2 - 3 } & Male & Female \\
\hline Not doing home work & 94.4 & 79.7 \\
\hline Talk in class room & 64.8 & 64.1 \\
\hline Uniforms & 58.5 & 64.1 \\
\hline Fight with friends & 84.9 & 76.6 \\
\hline Not listen to the teacher & 84.6 & 75.0 \\
\hline Other & 27.3 & 12.5 \\
\hline
\end{tabular}

CONSIDERATION OF SEX OF THE STUDENT WHILE CHOOSING TYPE OF ACTION BY MALE AND FEMALE TEACHER

Respondents were requested to give an idea about whether they choose the type of action to be introduced according to the sex of students or not. Majority of the teachers that is $38(69.1 \%)$ out of 55 male and $58(90.6 \%)$ out of 64 female disprove the selection of disciplinary actions according to the sex of 
the students (Table 3). Teachers expressed the reason for treating both male and female students identically in diverse way and they were: a. Students should be equal for the teacher regardless to their sex; b. Anti gender discriminatory law of the government contemporary society; c. Because of the negative psychological impact of discrimination, students might be spoiled and might show different attitude like stubbornness, aggressive etcetera; d. Though boys and girls are biologically different, the disciplinary actions should be selected according to their mistakes, not according to sex; e. If teacher excused girls from punishment, they (girls) will be spoiled and would not study, and on the other hand boys will not listen to the teacher expecting teacher would also excuse them (boys); and $\mathrm{f}$. the teacher's own disciplining style for example teacher do not use any physical action but try to convince students until they (students) fully convinced.

In general, both male and female teachers use same type of disciplinary actions for boys and girls, albeit it differs in severity and degree for example fewer sit-ups, lighter spank for girls. On the other hand there are some teachers who take the sex of the students into account while selecting disciplinary actions. Study shows that more male teachers that is 17 out of $55,(30.9 \%)$ than the female teachers that is 6 out of $64(9.4 \%)$ choose the action type according to the sex of the students. In comparison to female teacher, male teacher consider the sex of the students while selecting the type of disciplinary actions.

Table3: Considering Sex by Teachers while Selecting Disciplinary Actions for School Children

\begin{tabular}{|l|c|c|c|}
\hline \multirow{2}{*}{ Sex of teachers } & \multicolumn{3}{|c|}{ Considering sex (responding in percentage) } \\
\cline { 2 - 4 } & Yes & No & Total \\
\hline Male & 30.9 & 69.1 & 100 \\
\hline Female & 9.4 & 90.6 & 100 \\
\hline
\end{tabular}

REASONS FOR CONSIDERING SEX OF THE STUDENTS WHILE SELECTING DISCIPLINARY ACTIONS

As per male teachers, they choose physical actions like beating, spanking on the back with big sound, more laps of running in the school compound, more sit ups, other harsh punishment; and repetition of same home work for 4, 5 times, threats etc. Threats might be in the form of warnings like sending students to the office, complaining to the parents or punishing the male students physically. The reason for considering the sex of the students were associated with boys' different types of in-disciplinary behavior, committing more mistakes, stubbornness, not doing home work, being more aggressive with verbal action, making more mistakes, high chance of being spoiled, disobedient to the teacher, while trying to counseling boys attitude of saying "okay I won't do it again" but don't putting into practice, and physical strength. Few teachers expressed their reason for selecting different disciplinary actions as "They are male so they are physically strong, and can handle harder punishment than girls". Last but not the least, because of the same sex when they (male teacher) touch the boys it would not be an issue of gender. Conversely, to the girls, male teacher either do not prefer physical punishment or pick the lighter disciplinary actions, though the type of action is same in nature they apply it into lighter form or in less quantity like fewer laps of running, fewer sit ups etc. It was quite interesting 
to know that some time girls were excused to do sit ups just because of their inability to underwear. Some teachers ask the girls to push the wall with full force to correct their behavior. In most cases male teacher prefer verbal warnings or actions, holding student's own ear, light beating with stick, repetition of home work etc and avoid the disciplinary actions that demands teacher to touch the girls physically. The reason is, if male teacher touched the female students it might be an issue of assault. Some other responsible factors that force male teacher to excuse female students in their own prospect are: girls' physical and emotional weakness, commitment of fewer mistakes than male students and acceptance of the mistakes easily.

Unlike male teachers, the number of female teachers selecting disciplinary actions according to the sex of the students is very low. Those who consider the sex of the students, they said that some time they spank, scold and ask the boys to do sit-ups with holding ear if they did not stop unwanted behavior after repeated verbal warnings. The reason for selecting different action resembles the reason mentioned by male teachers. The reason for using such actions was associated with boys' hyperactive and stubborn attitude, repeated mistakes etc. On the other hand female students were found to be making relatively fewer mistakes, following instructions, frightened with seeing friends getting punishment are convinced easily and stop unwanted behavior after verbal action/warnings. So, female teachers give extra class work to keep the girl students so that they (students) could not talk. During the interview period with administrative staff and teaching staff it was also learnt that boys get more disciplinary actions in office as well as in the classrooms.

\section{SIGNIFICANT DIFFERENCES IN MALE AND FEMALE TEACHER'S ATTITUDE TOWARD DISCIPLINARY ACTION}

A chi square test was run to examine if the male and female teachers showed different attitude toward disciplinary actions. In comparison to female teacher, more male teachers were concerned with the sex of the students while selecting the types of disciplinary actions. The correlation between the sex of the respondents and consideration of the sex of the students is significant at 0.003 levels.

In majority of disciplinary action type, both the male and female teachers show similarities in using the type of disciplinary actions. Significant differences in some action type like sending students to the office or discipline in charge $\left(x^{2}=3.048 p=0.081\right)$ and threat $\left(x^{2}=3.116 p=0.078\right)$ (Table 4) were observed. Male teachers show higher intensity to threaten and send students to the office. Though the differences were insignificant, female teachers tend to threat students by saying "I will take you to the office, talk to your parents, or beat you with stick" and so on to correct their behavior. 
Table 4: Significant Differences in Types of Actions Taken by Gender wise Question No 1: Sends students to the office/discipline in-charge to correct student's unwanted behavior

(1) Yes

(b) No

\begin{tabular}{|l|l|l|l|l|}
\hline & Total & (a) & (b) & \multirow{2}{*}{$\mathrm{x}^{2}=3.048 \mathrm{p}=0.081$} \\
\cline { 1 - 4 } Male & 55 & 21 & 34 & \\
\cline { 1 - 3 } Female & 64 & 15 & 49 & \\
\cline { 1 - 3 } & &
\end{tabular}

Question No 2.Threatens students to correct unwanted behavior

(a) Yes

(b) No

\begin{tabular}{|l|l|l|l|l|}
\hline & Total & (a) & (b) & \multirow{2}{*}{$\mathrm{x}^{2}=3.116 \mathrm{p}=0.078$} \\
\cline { 1 - 4 } Male & 55 & 24 & 31 & \\
\cline { 1 - 3 } Female & 64 & 18 & 46 & \\
\cline { 1 - 3 } & \multicolumn{1}{|l|}{} &
\end{tabular}

Question No 3. Do you consider the sex of the students, while selecting disciplinary actions?

(a) Yes

(b) $\mathrm{No}$

\begin{tabular}{|l|l|l|l|l|}
\hline & Total & (a) & (b) & \multirow{2}{*}{$\mathrm{x}^{2}=8.797 \mathrm{p}=0.003$} \\
\cline { 1 - 4 } Male & 55 & 17 & 38 & \\
\cline { 1 - 4 } Female & 64 & 06 & 58 & \\
\hline
\end{tabular}

Gender wise significant disparity in the reason for taking action against students was also observed in few aspects. Male teachers were found to be more concerned with studious matter and other behavior reasons like stealing, gang fight etc. The significant differences were $0.020\left(\mathrm{x}^{2}=5.442 \mathrm{p}=0.020\right)$ levels for not doing home work and at $0.042\left(\mathrm{x}^{2}=4.356 \mathrm{p}=0.037\right)$ levels for other reasons (Table 5). Though no significant differences were found, female teachers were found to be more concerned with uniforms.

Table 5: Significant Differences in Reason for Taking Actions by Gender wise

\begin{tabular}{|c|c|c|c|c|}
\hline \multicolumn{5}{|c|}{$\begin{array}{l}\text { Question No 1. Action taken for not doing home work. } \\
\text { (a) Yes } \\
\text { (b) No }\end{array}$} \\
\hline & Total & (a) & (b) & \multirow{3}{*}{$\mathrm{x}^{2}=5.442 \mathrm{p}=0.020$} \\
\hline Male & 54 & 51 & 3 & \\
\hline Female & 64 & 51 & 13 & \\
\hline \multicolumn{5}{|c|}{$\begin{array}{l}\text { Question No 2. Action taken for other reasons } \\
\text { (a) Yes } \\
\text { (b) No }\end{array}$} \\
\hline & Total & (a) & (b) & \multirow{3}{*}{$\mathrm{x}^{2}=4.356 \mathrm{p}=0.037$} \\
\hline Male & 54 & 15 & 39 & \\
\hline Female & 64 & 8 & 56 & \\
\hline
\end{tabular}

\section{DISCUSSION}

Study shows that majority of the teachers are aware of the negative aspect of the disciplinary actions and prefer counseling or verbal action. When students become uncontrolled, they try different techniques of discipline. Some of 
the actions taken against not doing/completing home work i.e. keeping students after school and making them complete home work, giving extra home works, asking questions from the lesson seems to be natural and related consequences. But the way it is used is as punishment and harassing students. Students might be fed up with teacher's such behavior and develop stubborn and aggressive attitude. Before taking such actions teachers should try to find out the reasons. It can be assumed that the reason of not completing or doing home works might be associated with the issues raised by different scholars in the Nepali National Daily News papers like school administration's and parental higher expectation, tough curriculum, overloaded home work, absence of academic guidance at home, unclear class room instruction because of unscientific teacher and students ratio and the problem of load shedding the nation is going through. Students are getting actions just because of those reasons which can not be corrected only by the student's efforts. It also have been mentioned in the news papers that students are being freed from daily scolding of the teacher and started to be regular in the class room after getting electricity (Pandey, 2010). If addressed properly, most of the cases of punishment will be automatically reduced. Other actions/ techniques like financial charge and physical actions are negative consequences and should be completely stopped.

The study finding is similar to the results of Houston (1987) in the sense that teachers respond male and female students differently while taking disciplinary actions. Higher number of male teachers considers the sex of the students while selecting disciplinary actions. They often pick harsher techniques for male students to correct their unwanted behavior. On the other hand, they pick lighter punishment for female students considering their physical and emotional weaknesses. As a result, boys are the victims of gender discrimination at school levels for disciplinary actions. Both male and female teachers also mentioned the boy's stubborn attitude as the main reason for boys to get harsher punishments. It might be a question;

(1) Whether the male children are stubborn in their attitude by their birth or the continuous punishment and the discrimination they feel irritates them and continue the unwanted behavior?

(2) Do the teachers who use harsh punishment had have same type of punishment during their childhood?

As other foreign teachers Nepalese male teachers are more concerned with students' academic performance while female teachers are concerned with student's cleanliness. It can be related to the study done by Bailey (1992) and can be assumed that during school age girls are encouraged to be neat, quiet, and calm; consequently as they turn into adulthood they also expect the same from the students. It also can be related to the conclusion made by Farrington, 1993, Eron and Husemann 1984; and concluded that the boys in schools are getting harsher punishment and have higher chances to be more aggressive during their adulthood, which in turn may lead violation or discrimination against the women in general. 


\section{CONCLUSION}

In Nepal teachers still follow the traditional way of disciplining children. Despite of teacher's awareness toward children's right to learn in child friendly environment and hesitation to use the word "action", diversity of disciplinary techniques/actions such as making students ashamed, stand in front of the class mates or in front of seniors and juniors, sending to the office if not controlled by regular teacher, spanking, talking/complaining to the parents, sit ups, threat, financial charge, ear pulling are still prevalent in Nepalese schools. Disciplinary actions are applied by the teachers from class one. In the beginning the mild types of techniques/actions are applied but as the students are upgraded, the techniques/actions turns into severe or higher in degree. Boys and girls sit in the same class, learn same lesson, follow the same rules but get different actions because of their sex. A female teacher can touch both boys and girls but when the male teachers touch the girl it might be an issue. So male teachers like to be in safe side and avoid those actions/techniques which demands physical contact with female students. School boys are the victim of gender differentiated behavior of the teachers because of gender discriminatory perceptions. So called "physical strength of the boy versus weak physiology of girls"; " Boys have high possibility to be spoiled versus girls have less possibility of being spoiled"; attitude and the societal norms that do not allow males to touch the girls, are determinant factor of differentiation.

Acknowledgement: The author would like to thank University Grant Commission, Nepal for providing funding support for conducting this study. I would also like to thank Meelan Bhattarai and Mana Kafle for their support to prepare this article.

\section{WORKS CITED}

Eron, L.D. and L.R Huesmann. (1984). The control of aggressive behavior by changes in attitudes, values and the condition of learning. In advances in the study of aggression. Vol. 2, edited by R.J. Blanchard and C. Blanchard, Academic Press, New York.

Farrington, D.P. (1993). "Child hood Origins of teenage antisocial behavior and adult social dysfunction." Journal of the royal society of medicine, 1316.

Ganter and Yeakel, (1980). Cited by Tasmajian, Danielle (2002). Socialization skills acquired by elementary school children. Undergraduate Research Journal for the Human Sciences. ISBN 1-929083-13-0. Volume 1, 2002, Retrieved on March 4, 2011 from http://www.kon.org/urc/ tasmajian.html.

HMG; Culture, Tourism and Ministry of Civil Aviation; UNDP, TRPAP (2006). Gender equity, Women's health and HIV and AIDS orientation for prowomen rural tourism development. pp. 50-53.

Houston Barbara (1987). Should Public education be Gender-free? In G.H. Nemiroff (ed.), Women and Men: Interdisciplinary readings on gender. Fitzhenry and Whiteside, Canada, pp.134-149.

Kathmandu Post (2005). Child psychology Counselor essential: News report. National daily news paper June, 27. 
Kantipur (2005). 'Guruharule sike danda nadie sikaune seep') literal meaning 'Teachers learnt no punishment teaching skill." National daily News paper. November 2.

Kantipur (2010). "Bidyarthilai pandhra chadkan." literal meaning (Fifteen slap to the students) National Daily news paper. October 3. Year 18, No. 227, p. 9.

Naya Patrika (2009). "Sixyak ko kutai bata sorha bidyarthi ghaite”literal meaning "Teacher's beat injured sixteen students." National News Paper. June 15, p. 1.

Pandey, Tularam (2010). Bijuli bale pachhi bidyarthi niyamit literal meaning Students Regular after getting electricity. Kantipur. National daily news paper, November 6, p. 10.

Pokharel, Samidha (2010). "Gender socialization and its impact on children." Voice of teachers. A yearly journal of TUTA. Padma Kanya Multiple Campus. 2(2) 104-109.

--- (2005). Self-discipline among youngsters. The Kathmandu Post. National daily news paper. Vol. XIII, No. 31 (March 20), 4.

Pokharel Samidha; Bhattarai, Meelan; Kafle, Mana (2010). Adopting policy and practices of disciplinary actions/techniques at school education in Kathmandu valley. Submitted (Draft copy) to University Grant Commission.

Rajdhani (2009). Yatana dine sixyak niskasit literal meaning. "Teacher who torture child, displaced."

Rajdhani (2008). "Bidyalayama yatana badhyo." literal meaning "Torture rise in schools" study. Wednesday July 16, pp. 10.

Tasmajian, Danielle (2002). Socialization skills acquired by elementary school children. Undergraduate Research Journal for the Human Sciences. ISBN 1-929083-13-0. Volume 1, 2002, Retrieved on March 4, 2011 from http://www.kon.org/urc/tasmajian.html

Thorne, Barrie (1993). Girls and Boys Together.. But mostly Apart: Gender Arrangement in elementary Schools; In Laurel Richardson /Verta Taylor (eds.). Feminist Frontiers III. NY; McGraw-Hill, Inc, pp. 115-126. 